\title{
Designing e-Local Content of Teaching Materials for Extensive Reading Course: Lecturer's Voice
}

\author{
Vebrianti Umar ${ }^{1 *}$
}

${ }^{1}$ STKIP Islam Sabilal Muhtadin Banjarmasin

\begin{abstract}
This research focus on designing e-local content of teaching materials for extensive reading course: Lecturer's voice. It applied R\&D based on ADDIE MODEL. ADDIE means Analysis, Design, Development, Implementation and Evaluation. Furthermore, Interview and questionnaire as the instrument of collecting data. The result of this research revealed that the lecturers interested to use this reading material for teaching extensive reading course. It is proved by the positive response given by the lecturer. From 19 distributed questions, 18 questions has Yes response (1). The percentage of the score 1 is $100 \%$, and it categorized as excellent. Moreover, 1 question has No (0)response, and the category of score 0 is poor. Refers to the gathered score, the ELocal Content of teaching materials is feasible to use as the appropriate reading materials for teaching extensive reading course based on lecturer's voice.
\end{abstract}

Keyword: local content, electronic materials, extensive reading course

\section{INTRODUCTION}

Reading is an English skill that involving the process to gain information or knowledge from some source, such as book, magazine, article, newspaper, etc. Reading is categorized complex skill, because it involved lexical and text. It is line with Loucky (in Ferdila, 2014:68) reading is a difficult skills, multi-faceted activity, combining lexical and text progressing skill that is known as being interactive" therefore, it is important to apply extensive reading in the reading process to ease the readers. Based on the observation at an University in Banjarmasin, Extensive Reading is a course that taught at third or fourth semester students. According to the lecturer who taught Extensive Reading course, the reading materials should be easy and interesting to read, because the students should enjoy the reading material.

However, pandemic Covid-19 causes the change of teaching and learning process from offline mode to online mode. The process of teaching and learning should be done at home through application, such as zoom meeting, google meet, google classroom, even WhatsApp. Basically, the aim of the online mode is supported Government Regulation in order to avoid the spreading of corona virus disease. In this case, the lecturer need an appropriate extensive reading materials for supporting the online teaching and learning of Extensive Reading Course. Moreover, the extensive reading materials also should be suitable

*Corresponding author: barendz.umar@gmail.com

To cite this article: Umar, V. (2022). Designing e-Local Content of Teaching Materials for Extensive Reading Course: Lecturer's Voice. Ebony --- Journal of English Language Teaching, Linguistics, and Literature, 2 (1) 2022, pp. 1-13. 
with the RPS (Rencana Pembelajaran Semester). Moreover, teaching of extensive reading course, the lecturer should apply appropriate reading materials for supporting the process. Hedge (in Ferdila 2014:69) stated that actually extensive reading has a concept related to expose students about input-rich and enjoyable environment, with the purpose that their language competency will improve and their learning enthusiasm also will develop.

According to Bamford and Day (in Puspitsari 2019:35), as the materials provider in extensive reading course, the teachers are required to understand clearly the appropriate reading book that should be read by the students. Moreover, Bamford \& Day (in Delfi\&Yamat,2017:169) explore ten principles of extensive reading: 1) The extensive reading material should be easy to learn, (2) the reading materials should be varied with a wide range of topics (3) the students are free to select what they want to read (4) The students read as much as possible, (5) Reading speed s usually faster rather than slower, (6) The purpose of reading is usually related to pleasure, information and general understanding, (7) Reading is individual and silent, (8) Reading is own reward, (9) The teacher orients and guides students, (10) The teacher is a role model of a reader.

Based on the statement above, the lecturer apply two kinds reading material for teaching extensive reading course referring on RPS, those are fiction and non fiction stories with genres romance, fantasy, adventure, horror, biography and autobiography. Manuel and carter (in Puspitsari 2019:35) pointed out that over 50\% students prefer to read fiction book rather than to read other types of book. Moreover, the female students more like to the book of fantasy, mystery, detective, and action and adventure while the male students more happy to read science-fiction more than other genres.

In addition, the lecturer suggested to the students to read the fiction and non fiction stories from various source, those can be novel, newspaper and magazines. However, in this crucial situation of Covid-19 the lecturer had difficulty to teach extensive reading course because the teaching and learning process should be done at home to avoid the spreading of corona virus disease. In this case, the lecturer should teach the extensive reading course from home through zoom application. Moreover, the lecturer also should recommend the appropriate digital reading material in extensive reading course. The process of teaching and learning called as online learning, because the teacher and the students are in different places. Additionally, they also utilizing internet for accessing digital material and interacting with the teacher and other students. As claimed by Anderson (in Rapanta et all, 2020:925) online learning refers to a type of teaching and learning situation in which the teacher is at distance from the learner, the process of teaching and learning using technology to access the learning materials and to interact among teacher and learners. Therefore, it is important to apply the appropriate instructional material for teaching the course of extensive reading. As stated by Ikerionwu (in Ajoke, 2017:40), instructional materials are the assistant tool that helps the teacher in presenting a lesson to the learners in a logical manner. Agina-Obu (in Ajoke, 2017:40) submits that instructional material is the attractive thing that supports teaching and learning process.

Richards (in Manurung, 2017: 88) argued that instructional materials are vital in most language programs. Whether the teacher uses a textbook, institutionally prepared materials, or materials, instructional materials generally serve as the basis for much of the language 
input learners receive and the language practice in the classroom. Moreover, Crawford (in Manurung, 2017: 90) stated that the instructional materials must be realistic and contextual. Additionally, Crawford (in Manurung,2001:84) argued that effective teaching materials reflect the following statement; Language should have function and context, the development of language requires learner engagement in the purposeful use of language, the use of language should be realistic and authentic, classroom materials will usually seek to include an audiovisual component, effective teaching materials foster learner autonomy, materials need to be flexible enough to cater to individual and contextual differences, and learning needs to engage learners both affectively and cognitively.

Furthermore, Crawford (in Manurung, 2017: 90) argued that the instructional materials must be effective; this is an essential point in instructional material. Therefore instructional materials must be appropriately developed so that the materials can motivate effective and joyful learning.

Actually, there are some types of instructional material that can be applied in the process of teaching and learning. Sari (2017:64) quoted from Depdiknas, "instructional materials consist of printed materials such as hand out, module, students' worksheet, leaflet, wall chart; audiovisual such as film, VCD; Audio such as radio, cassettes, CD, audio; visual such as photographs, picture, model, and multimedia such as Interactive CD, computerbased, and internet."

Moreover, Yusuf (in Ajoke, 2017:40) said learning materials could be classified into several ways. Such as auditory, visual, and reading materials are :

1. Printed and reference materials: Textbooks, newspapers, magazines, government documents, teachers ${ }^{\text {ee }}$ guide book, duplicated materials, journals, handbook bulletins, pictures, workbooks, pamphlets, leaflets, modules etc.

2. Graphic materials: Graphs, charts, diagrams, maps, globes, tables etc.

3. Display materials: Chalkboard, bulletin boards, flat pictures, magnet boards, and flannel board.

4. Projected materials - television, videotape, overhead projector, slides, slide projector, and transparencies.

5. Audio and other visual materials: Radio, model, computer, tape recording, phone, laptop, notebook etc

6. Community resources: Zoos, Agricultural extension service centers, marketplace, parks, industrial establishments. In reading skill, instructional material

Refers to the description above, the researcher conducted this research to design ELocal Content of Teaching Materials for Extensive Reading Course. However, this research provided the student's voice only. In addition, this electronic teaching materials integrated Banjar local content, in which stories from Banjar, in line with Manurung et al (in Manurung, 2017:94) local content can be involved as the supplement of instructional process of teaching materials.

Sapia Husain et al ( 2019:68) quoted "Local content is a study material for students' comprehension of their local potential, as provided for in Elucidation of the Law Number 20 Year 2003 on national education systems. The Government Regulation Number 32 Year 2013 Article 77N on Amendment to the Government Regulation Number 19 Year 2005 on 
National Standards conveys that (1) Local content shall include a learning process, local specific features and potential for any educational unit; (2) All educational units shall develop and incorporate local content."

The role of the local content provides learners with real examples that can be directly experienced during and after the instructional process. Moreover, Manurung (2014: 92) also reported that the role of autonomous learning materials and integrating the local content material into learning materials development improve the achievement in the instructional process.

Moreover, Utami (in Monica \& Vianty, 2019:2) proved that The reading material which integrated with culture or local conten can effectively assist the students to understand the content, because it connect to their daily life. It is line with Malone ( in Monica \& Vianty, 2019:2) stated that the alternative way that can be used by EFL teacher to help the students become life-long readers is by providing the students with information or reading materials which are relevant to students ${ }^{\text {ee }}$ life, heritage and culture, such as the story from the local content dealing with local people, object and events.

Concerning to the explanations above, the researcher would insert Banjar local content in the E-instructional material for teaching Extensive Reading Course. The local content can be like Fiction and Non Fiction (General), Fiction and kinds of fiction stories with genres of thriller story, romance story, Science Fiction/Fantasy story, adventure story, and Autobiography/Biography which are related to Banjar. Furthermore, before selecting the instructional reading materials, it is important to know the criteria of Good instructional English reading materials. Clarke (in Sari, 2016 :64) concluded that good learning materials should have the characteristics above. It should be authentic, realism, based on the context, and focus on the learners' needs.

Authentic: Peacock (in Sari, 2016:64) stated authentic materials is the materials that is made to support the goal of language community in socially. Richards (in Sari,2016:64) added that authentic materials refers the aids that is used in teaching. Such as photographs, video selections, and other teaching resources that were not specifically prepared for pedagogical purposes. Realism: The instructional material has to be accurate. It can be seen and touched to help the learner to understand the materials easily. It should be fixed with the context means involving the classroom situation, the student, and the subject being taught. Focus on the learners' needs: The instructional materials should make the students focus on the learning process. Therefore, the instructional materials used by the teacher should be focus on the needs of the student. Richards (in Manurung, 2017:96) argued that in the process of constructing regarding the role of materials in a language program are made, it is important to decide the initial as concerning the use of authentic materials versus created materials.

The teaching and learning process has been changed since the online learning mode was applied. It pushes the teacher to determine the appropriate materials for the online learning mode. To help the online teaching and learning process especially reading, the researcher will try to make the instructional material electronically. Learning according to OECD (in Arkorful \& Abaidoo, 2014:2), is defined as the use of information and communication technologies in diverse processes of education to support and enhance 
learning in institutions of higher education and includes the usage of information and communication technology as a complement to traditional classrooms, online learning or mixing the two modes.

Meanwhile, according to Abbad et al (in Arkorful \& Abaidoo, 2014:2), it is defined E-learning to mean any learning that is enabled electronically. Moreover, Welsh et al. (in Arkorful \& Abaidoo, 2014:398) also stated that E-Learning is the process of learning using computer network technology, supporting by internet to provide information and instruction to individuals.

Furthermore, Algahtani (in Arkorful \& Abaidoo, 2014:399 classified e-learning into two main types, those are E-learning computer-based and the E-Learning internet- based . Algahtani also defined Computer-based learning involves the full use of hardware and software commonly available for information and communication technology use, and each component can be used in two ways: Computer managed instruction and computer-assistedlearning.

In computer-assisted-learning, Computers are used instead of traditional methods by providing interactive software as a classroom support tool or as an out-of-class study tool. However, in the control system of algorithms, computers are used to store and restore targets. Information to help manage education.

Meanwhile, Almosa (in Arkorful \& Abaidoo, 2014:399 pointed out computerassisted-learning is a further improvement of the computer-based learning, and it makes the content available on the internet, with the readiness of links to related knowledge sources, for examples e-mail services and references which could be used by learners at any time and place as well as the availability or absence of teachers. From those definitions, it can be understood that e-learning deals with the use of electronic media in transferring or supporting teaching and learning process. It means that the electronic instructional material of reading is the material which delivered by the lecturer electrically or by using electronic media such as phone, notebook, laptop or computer and internet as the supported of it.

In this research, the E-reading material would be in Portable Document Format (PDF). PDF is a digital document that is embedded by many types images, forms, and text. The file / document can be downloaded with internet supporting and the file can be saved in phone, notebook, laptop or computer. PDF documents are one of the maximum popular layout for publishing e-books nowadays. This recognition is due to the wrapping ability of the PDF document, i.e.: it wraps or embeds many styles of data (photographs, paperwork, texts, fonts etc.).

\section{METHOD}

This research applied Research and Development (R \& D) based ADDIE MODEL (by Branch, 2009) which aimed Designing E-Local Content of Teaching materials for Extensive Reading Course. Aldoobie (in Fergina, 2019:30) pointed out ADDIE model categorized as the most effective model used in designing learning materials. Moreover, Branch (2009:2) stated that ADDIE is an acronym of five stage for Analyze, Design, Develop, Implement, and Evaluate. ADDIE is the concept of development product. 
There was interview to the lecturer and giving questions to the students on the analysis step as the first step because this step related to the finding the information related to the students' English competence and existing course books. What is the students' expectation about the English competence and the course books, and what is the purpose of learning English. On the second step, refers to designing the models of instruction in relating to language and learning theories and writing design of the instructional materials. This is a concept of E-instructional material or making outline of the E-instructional material. The third step was Development, in which the E-instructional material developed based on the concept or design. In this step, the E-instructional material should be evaluated by expert before continuing to the next step. The implementation step involve the use of EInstructional material based on Banjar local content in the process of teaching and learning Extensive reading course. The last step was about Evaluation. On this step, the Einstructional material should be evaluated based on the result of questionaire that distributed to the lecturer and students. To prevent the confusion and to make it simple, the researcher provide Branch (2009:2) for learning material design as follows:

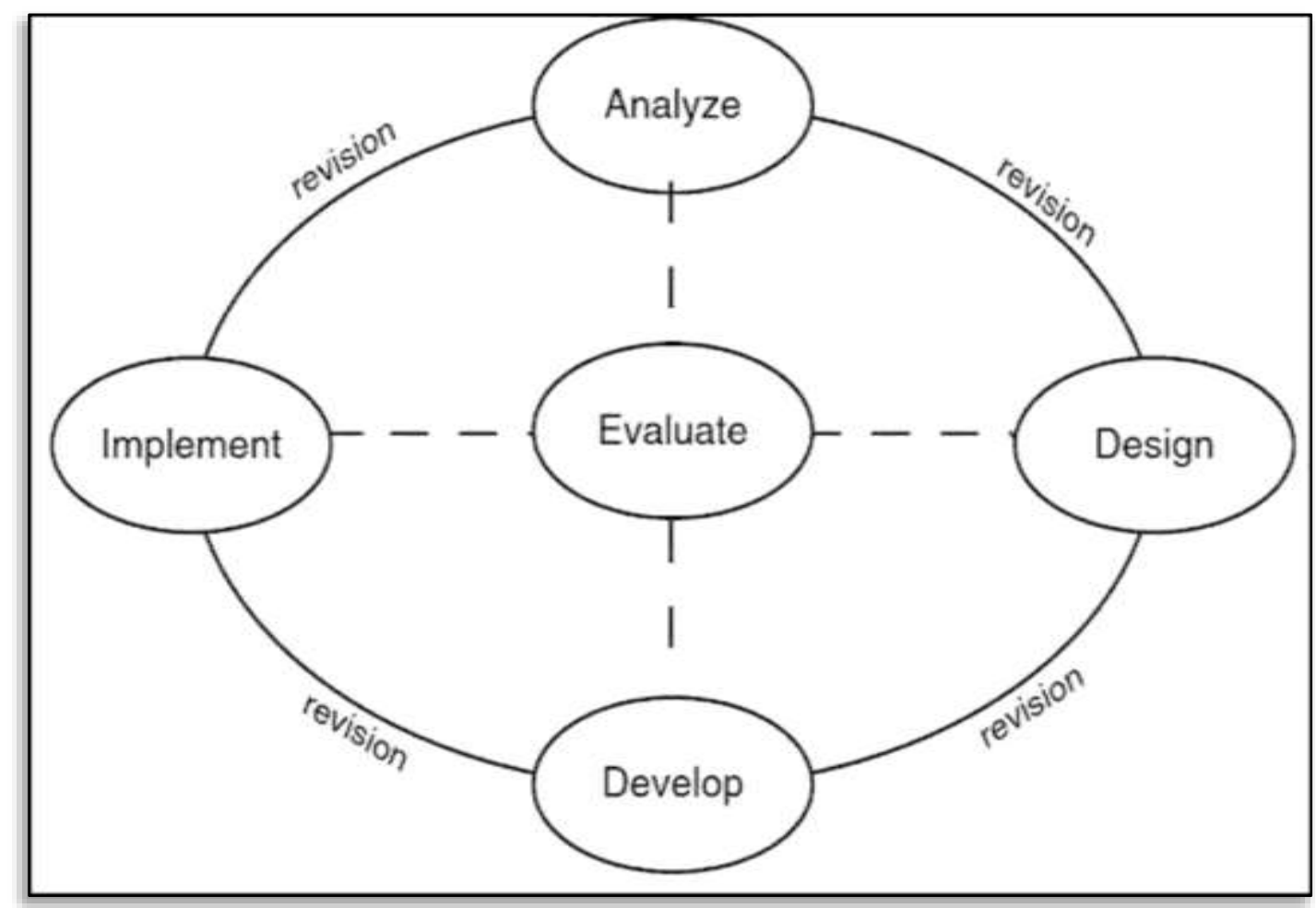

Figure 1 Core Elements for instructional Design (Branch, 2009)

Then, the following is the research framework. 


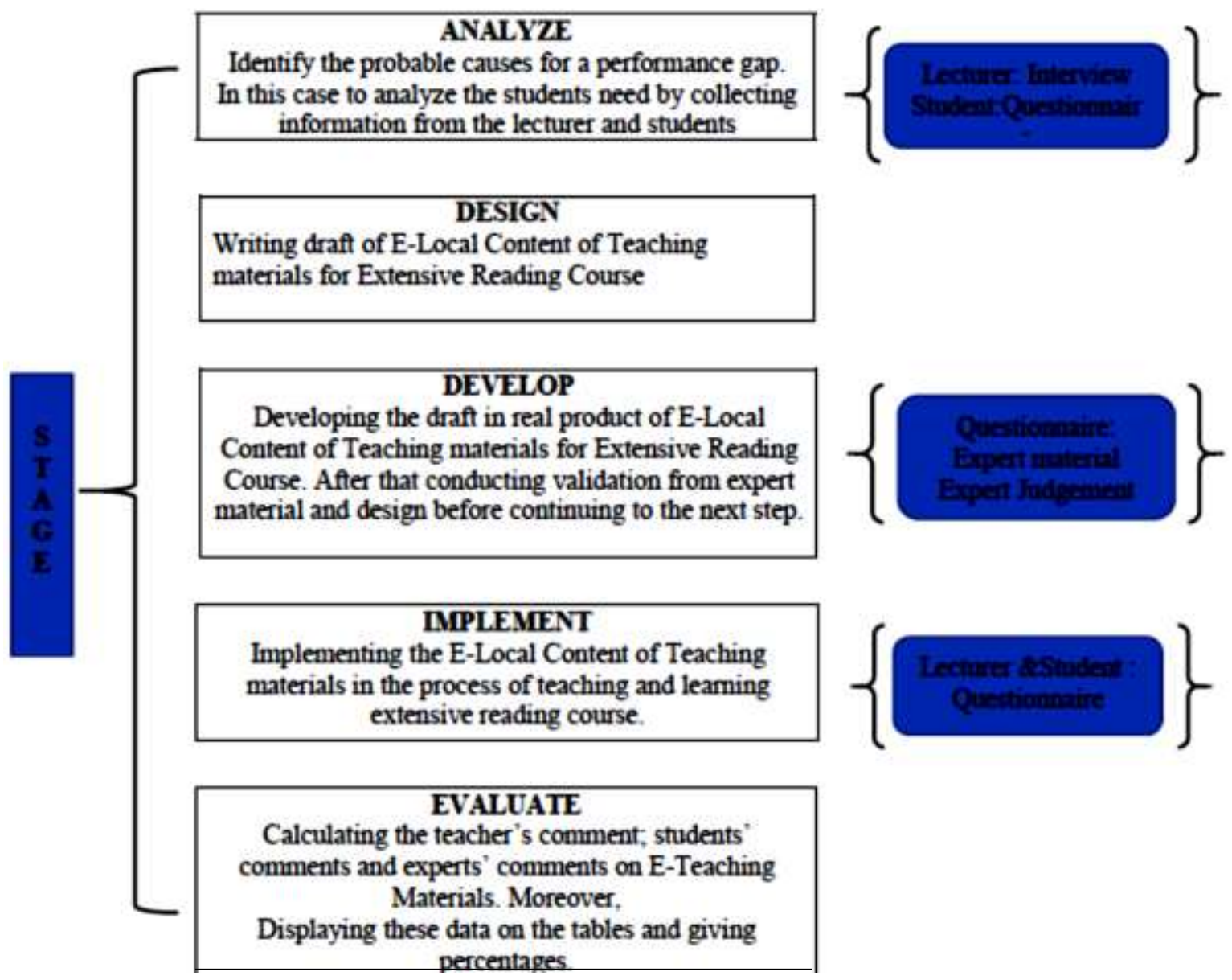

Figure 2. Research Framework

The respondents were the English lecturer of Lambung Mangkurat University who taught Extensive Reading course, the fourth semester students of Lambung Mangkurat University with total number 25, the expert of material and the expert of judgment. Meanwhile, questionnaire and interview used as the instrument of this research. The questionnaires were divided into two categories, first was for Expert material and expert design and the second was for the English lecturer and student. Gutman scale was used as the type of questionnaire. Forrester (2019:2) pointed out that Gutman scale analysis is a method that is used in social science. It provides two answers or responses, Yes and No, where Yes was scored as 1 and No was 0. Ari Kunto (Agustina et all,2018:4).

The questionnaire contains 17 questions which asked to affirm about the followings:

- the cover of electronic instructional material,

- the selected picture in the electronic instructional material,

- the color selected in the electronic instructional material,

- the presented text or story in the electronic instructional material,

- the stimulation form of the electronic instructional material,

- the coherence of material and RPS put in the electronic instructional material,

- the local content applied in the electronic instructional material,

- the material of Fiction and non fiction story in the electronic instructional material,

- the genre of story in the electronic instructional material, 
- the material of biography and autobiography in the electronic instructional material,

- the systematic of material in each unit,

- the suitability of exercises with the material taught in the electronic instructional material,

- the contribution of the instructional material for teaching the vocabulary and reading comprehension,

- the influence of the electronic instructional material in teaching extensive reading course,

- the involvement of Banjar local content in the electronic instructional material, and

- the advantage of the electronic instructional material towards the process of teaching extensive reading course.

Furthermore, all those questions were analyzed quantitatively based on the appropriate percentage. After the respondent giving response the questionnaire, the result would be analyzed quantitatively by using percentage. The categorize of score was calculated by using this formula :

Percentage $(\%)=\mathrm{F}(100 / \mathrm{N})$

Where

P : Percentage

$\mathrm{F} \quad$ : frequency

$\mathrm{N} \quad$ : Total of Respondents

100\% : Fixed Number (Adapted from Arikunto 2018)

Then, the percentage above are categorized into criteria below.

Table 2. Criteria of Percentage

\begin{tabular}{ll}
\hline PERCENTAGE & CRITERIA \\
\hline $81 \%-100 \%$ & Excellent \\
\hline $61 \%-80 \%$ & Very good \\
\hline $41 \%-60 \%$ & Good \\
\hline $21 \%-40 \%$ & Fair \\
\hline $0 \%-20 \%$ & Poor \\
\hline
\end{tabular}

\section{RESULTS}

Table 3 is the result of questionnaire that was distributed by the researcher to the lecturer. This questionnaire provided two response, Yes and No. The questionnaire based on Gutman Scale theory.

Table 3 Result of questionnaire

\begin{tabular}{lccc}
\hline \multirow{2}{*}{ Questions } & \multicolumn{2}{c}{ Response } & \multirow{2}{*}{ Category } \\
\cline { 2 - 3 } & Yes & No & \\
\hline the cover of electronic & 1 & 0 & Excellent \\
instructional material is & $(100 \%)$ & & \\
interesting and informative & & & \\
\hline
\end{tabular}




\begin{tabular}{|c|c|c|c|}
\hline $\begin{array}{l}\text { the selected picture in the } \\
\text { electronic instructional material is } \\
\text { appropriate and interesting }\end{array}$ & $\begin{array}{c}1 \\
(100 \%)\end{array}$ & 0 & Excellent \\
\hline $\begin{array}{l}\text { the color selected in the electronic } \\
\text { instructional material is } \\
\text { interesting }\end{array}$ & $(0)$ & $\begin{array}{c}1 \\
(100 \%)\end{array}$ & Poor \\
\hline $\begin{array}{l}\text { the presented text or story in the } \\
\text { electronic instructional material is } \\
\text { clear and easy to read }\end{array}$ & $\begin{array}{c}1 \\
(100 \%)\end{array}$ & 0 & Excellent \\
\hline $\begin{array}{l}\text { the stimulation form of the } \\
\text { electronic instructional material is } \\
\text { good and interesting }\end{array}$ & $\begin{array}{c}1 \\
(100 \%)\end{array}$ & 0 & Excellent \\
\hline $\begin{array}{l}\text { the material and RPS put in the } \\
\text { electronic instructional material is } \\
\text { coherent to each other }\end{array}$ & $\begin{array}{c}1 \\
(100 \%)\end{array}$ & 0 & Excellent \\
\hline $\begin{array}{l}\text { the material used in the electronic } \\
\text { instructional material contains the } \\
\text { local content }\end{array}$ & $\begin{array}{c}1 \\
(100 \%)\end{array}$ & 0 & Excellent \\
\hline $\begin{array}{l}\text { the material contains Fiction and } \\
\text { non fiction story in the electronic } \\
\text { instructional material }\end{array}$ & $\begin{array}{c}1 \\
(100 \%)\end{array}$ & 0 & Excellent \\
\hline $\begin{array}{l}\text { the genre of story in the electronic } \\
\text { instructional material contains } \\
\text { romanticism, fantasy, and horror }\end{array}$ & $\begin{array}{c}1 \\
(100 \%)\end{array}$ & 0 & Excellent \\
\hline $\begin{array}{l}\text { the material contains biography } \\
\text { and autobiography }\end{array}$ & $\begin{array}{c}1 \\
(100 \%)\end{array}$ & 0 & Excellent \\
\hline $\begin{array}{l}\text { the material is systematic in every } \\
\text { unit }\end{array}$ & $\begin{array}{c}1 \\
(100 \%)\end{array}$ & 0 & Excellent \\
\hline $\begin{array}{l}\text { the exercises given are suitable } \\
\text { with the material taught }\end{array}$ & $\begin{array}{c}1 \\
(100 \%)\end{array}$ & 0 & Excellent \\
\hline $\begin{array}{l}\text { the exercises given help teachers } \\
\text { teach vocabulary and reading } \\
\text { comprehension }\end{array}$ & $\begin{array}{c}1 \\
(100 \%)\end{array}$ & 0 & Excellent \\
\hline $\begin{array}{l}\text { the electronic instructional } \\
\text { material helps teachers teach } \\
\text { extensive reading course }\end{array}$ & $\begin{array}{c}1 \\
(100 \%)\end{array}$ & 0 & Excellent \\
\hline $\begin{array}{l}\text { the electronic instructional } \\
\text { material contains Banjar local } \\
\text { content }\end{array}$ & $\begin{array}{c}1 \\
(100 \%)\end{array}$ & 0 & Excellent \\
\hline $\begin{array}{l}\text { the electronic instructional } \\
\text { material is benefited to the } \\
\text { teaching of extensive reading } \\
\text { course }\end{array}$ & $\begin{array}{c}1 \\
(100 \%)\end{array}$ & 0 & Excellent \\
\hline Suggestion and Comment & $\begin{array}{l}\text { Overall, th } \\
\text { bright colc }\end{array}$ & goo & etter to apply the \\
\hline
\end{tabular}

Based on the data above, there were 17 questions that distributed to the lecturer. The fact revealed that 16 questions obtain positive response, in which all question is categorized as excellent. Meanwhile, one question related to color is getting No response. According to the lecturer, the cover of book of Electronic instructional material based on Banjar local content was interesting and informative. Therefore the score was categorized as the excellent 
or $100 \%$. moreover, the selected picture in the electronic instructional material was appropriate and interesting means the score was $100 \%$ or excellent. Meanwhile, the lecturer considered that the selected color applied in the electronic material was inappropriate and the lecturer also suggested and commented in order to apply bright color in E-Local Content of Teaching materials for Extensive Reading Course.

On the next question, the lecturer gave score $100 \%$ or excellent. It means that the text or story was easy to read. On the stimulation part, the lecturer agree that the stimulation provided in the electronic instructional material based on Banjar local content was good and interesting. Besides, the lecturer responded Yes towards the suitability of the instructional material and the semester lesson plan or RPS, means that the score was $100 \%$ or excellent. For the next question, the researcher agree that the electronic instructional material contain the Banjar local content, especially Banjar Story. Therefore, the score was $100 \%$ or excellent category. The next question, the lecturer give response Yes because the material contain fiction and non fiction story, and the score was $100 \%$ or excellent. Moreover, according to the lecturer, the material contains the romance story, fantasy story, and adventure story. Therefore, the lecturer response Yes or giving score $100 \%$ or excellent category. In addition, the electronic instructional material have biography and autobiography text. In this point, the lecturer response Yes $(100 \%)$ or excellent category. The next question is integrated to arrangement of unit systematically. The lecturer completely agree that the all the unit electronic instructional material has been arranged systematically by the researcher. Talking about the exercises, according to the lecturer it is suitable with the teaching material. It means that the score $100 \%$ or excellent category.

Then, the exercises also support the process of teaching vocabulary and reading comprehension. The question get score $100 \%$ or categorized as excellent. Based on the lecturer's evaluation, the electronic instructional material based on Banjar local content very useful for teaching extensive reading course. Therefore, the lecturer give score $100 \%$ or excellent category. The next question related to the integrating of Banjar local content in the electronic instructional material, and the lecturer find that all text and story involved Banjar local content. Therefore, the score is $100 \%$ or excellent category. The last question, the lecturer agree that the electronic instructional material based on Banjar local content is very interesting and supporting the teaching and learning of extensive reading course.

Referring to all the scores and the category above the researcher conclude that most question obtain the positive response or most questions has percentage $81 \%-100 \%$ on which the criteria is excellent. In contrast, 1 question was responded No by the English teacher. It means that the E-Local Content of Teaching materials for Extensive Reading Course is feasible to use as the reference for supporting the teaching of Extensive reading Course considered to the lecturer's voice

\section{DISCUSSION}

This research is related to the designing of E-Local Content of Teaching materials for Extensive Reading Course: Lecturer's voice. It means that this research only showed the lecturer's voice towards the E-Local Content of Teaching materials for Extensive Reading 
Course. The interview was taken to collect some information related to the extensive reading materials used by the lecturer. It is related to the electronic tools for supporting extensive reading course, inserting local content in reading materials, and also the importance of electronic references of reading materials for teaching Extensive Reading Course.

Meanwhile, the questionnaire was conducted to obtain the support data of interview. Furthermore, this E-Local Content of teaching materials for Extensive Reading Course : Lecturer's voice integrated with Banjar local content, in which some stories of Banjar. This E-local content consist on seven units in which involved fiction and non fiction stories with genre romance, horror, adventure, and fantasy.

According to the lecturer, actually this E-Local Content of teaching materials for Extensive Reading Course feasible to use as the reference of teaching extensive reading course based on the lecture's voice. Actually some previous research has been done similar research related to designing extensive reading materials. The research by Gustaf (2015). The similarity of the previous research with this research was about the materials developed for extensive reading. Nevertheless, it also cannot be denied that the researches had some differentiation, those are about this research developed extensive reading materials in electronic form, while the previous research was in form of comic book (printed book). Moreover, this research integrated local content, specifically the stories of Banjar, whereas the previous research did not have local content. In addition, the previous researcher developed book for Junior High School and applied R\&D based on Borg and Gall(1799)meanwhile the researcher of this reading materials developed teaching materials for university students and R\&D in ADDIE MODEL based on Branch (2009) applied as the research method.

Furthermore another previous research by Hidayat (2017) which studied applied research and development (R\&D) design consisted of needs analysis, developing materials, evaluation, and product try-out and revision. The subject of the needs analysis consisted of 33 students from junior high school in the seventh grade who represented three levels of ability (good, average, poor) and the English teacher. The product was evaluated by two experts who had the ability in technology and English Language teaching. The result showed that the developed interactive $\mathrm{CD}$ was acceptable for seventh-grade students. The research similar to this research in terms of electronic reading material, in which the reading materials was integrated with electronic. However, the previous researcher developed the reading materials only or it did not specific to the extensive reading material.

Additionally, the other research by Kusuma (2016) had similar result to this research in terms of local content, in which the reading materials was integrated with local content. However, the previous researcher developed the printed reading materials or textbook for elementary students. Meanwhile, the researcher of this research developed the specific one, not only about reading but for extensive reading course for university students. Moreover, the differentiation of previous research and this research was related to research method, where the previous one used R\&D based on Sugiyono (2011)and this research applied R\&D method with design of ADDIE MODEL based Branch (2009)

Referring to the discussion above, it can be concluded that designing E-Local Content of Teaching materials for Extensive Reading Course in terms of Lecturer's voice 
has similarity with some previous researches. However, this research tried to design reading materials in specifically for extensive reading course. Moreover, it is developed in the electronic form by integrating Banjar stories as the local content.

\section{CONCLUSION}

At university education level, extensive reading is a course that taught at third or fourth semester. The main activity of extensive reading course is reading. Moreover, The materials of extensive reading should be easy and interesting so as the students enjoy to read the material. However, in this complex situation of Covid-19, the process of teaching and learning should be done at home. Therefore, the teacher need teaching materials to support the extensive reading course. Based on the description above, the researcher designed an ELocal Content of Teaching materials for Extensive Reading Course. This research showed only the lecturer's voice of the E-Local Content of Teaching materials for Extensive Reading Course. The lecturer's voice viewed from the result of questionnaire that distributed to her. Refers to the result of questionnaire, the lecturer agree that the E-Local Content of Teaching materials for Extensive Reading Course. From the 19 questionnaire that distributed to the lecturer, 18 questions have Yes response and 1 question has response No. The score of Yes is 1 with percentage $100 \%$ and the score of No is 0 with percentage $0 \%$. The criteria of score 1 is excellent and score 0 is poor. Therefore, the conclusion of this research is the lecturer very agree and interested to use the E-Local Content of Teaching materials for Extensive Reading Course. It means that it feasible to use as the appropriate reference for teaching extensive reading course.

\section{REFERENCES}

Agustina, L., Harahap, A., \& Syahrial. (2018). Developing Reading Material Based-on Local Culture for Junior High School in Kabupaten Rejang Lebong. Journal of Applied Linguistic and Literature, 3(1), 1-14.

Ajoke, A. R. (n.d.). The Importance of Instructional Materials in Teaching English as a Second Language. www.ijhssi.org

Arkorful, V., \& Abaidoo, N. (2014). The role of e-learning, advantages and disadvantages of its adoption in higher education. Ijern, 2(2), 397-410.

Branch, R. M. (2009). Instructional Design: The ADDIE Approach. In Instructional Design. Springer Science+Business Media.

Delfi, S., \& Yamat, H. (2017). Extensive Reading in Developing Language Competency for Indonesian EFL Learners Majoring in English. IJELTAL (Indonesian Journal of English Language Teaching and Applied Linguistics), 1(2), 153. https://doi.org/10.21093/ijeltal.v1i2.20

Ferdila, R. (2014). the Use of Extensive Reading in Teaching Reading. Journal of English and Education, 2014(2), 68-80.

Fergina, A. (2019). Preserving Local Wisdom Through Extensive Reading Book

“ Traditional Games Of Indigenous People In West Kalimantan .” UHAMKA 
International Conference on ELT and CALL (UICELL, November, 21-22.

Forrester, R. (2016). Guttman Scale Analysis and Its Use to Explain Cultural Evolution and Social Change. SSRN Electronic Journal, 1-7.

https://doi.org/10.2139/ssrn.2866015

Gustaf, D. (2015). Designing A Comic Book for Extensive Reading Material for 8 the Grade Students of SMP N 2 Sanden. State University of Yogyakarta.

Husain, S., Panai, A. H., Abbas, N., \& Uno, H. B. (2019). Development of Local Content Learning Module for Karawo Embroidery Crafts in Vocational High Schools in Gorontalo. Journal of Education and Practice, 10(15), 66-76.

Kusuma, I. P. I. (2016). DEVELOPING READING MATERIAL FOR ELEMENTARY STUDENTS IN TOURISM AREA BY INSERTING LOCAL CULTURE. JEELS (Journal of English Education and Linguistics Studies), 3(1). https://doi.org/10.30762/jeels.v3i1.176

Manurung, K. (2017). DESIGNING INSTRUCTIONAL MATERIALS (I, Issue July). UNTAD Press.

Monica, S., \& Vianty, M. (2019). Developing Local Content-Based Instructional Graded Reading Materials for Reading Level Three Students. Linguistic, English Education and Art (LEEA) Journal, 3(1), 1-16. https://doi.org/10.31539/leea.v3i1.792

Puspitasari, E. (2019). “I Love Creepy Pasta”: EFL Students' Book Selection for Extensive Reading. Advances in Social Science, Education and Humanities Research, 353(IcoSIHESS), 50-55. https://doi.org/10.2991/icosihess-19.2019.8

Rapanta, C., Botturi, L., Goodyear, P., Guàrdia, L., \& Koole, M. (2020). Online University Teaching During and After the Covid-19 Crisis: Refocusing Teacher Presence and Learning Activity. Postdigital Science and Education, 2(3), 923-945. 